\title{
ANGELS AND DEMONS NOVEL - A MILESTONE IN DAN BROWN'S CREATIVE WORK
}

\author{
CMuratova E., ORCID: 0000-0003-3041-0820, Ph.D., Uzbekistan State World Languages \\ University,Tashkent,Uzbekistan,elmira-muratova@list.ru \\ CPulatova D., ORCID: 0000-0002-5509-9584, Uzbekistan State World Languages University, \\ Tashkent,Uzbekistan, pdiyora@inbox.ru
}

\section{РОМАН «АНГЕЛЫ И ДЕМОНЫ» - ВЕХА В ТВОРЧЕСТВЕ ДЭНА БРАУНА}

\author{
Myратова Э., ORCID: 0000-0003-3041-0820, канд. филол. наук, Узбекистанский \\ государственный университет мировых языков, \\ 2. Ташкент, Узбекистан, elmira-muratova@list.ru
}

Пулатова Д. Ф., ОRCID: 0000-0002-5509-9584, Узбекистанский государственный университет мировых языков, г. Ташкент, Узбекистан, pdiyora@inbox.ru

Abstract. Nowadays the genres eclecticism is so widespread that it is sometimes impossible to identify to which genre a work belongs. This situation, in turn, is reflected in the blurring of the frontiers between Highbrow and Lowbrow literature. Moreover, there are novels that contain some elements of Pulp fiction, and yet they do not belong to this type of literature. This situation is particularly topical with the works that open a series of sequels exploring the same theme or featuring the same protagonist, like the novel under our investigation. This research has proved that this novel contains artistic merit and cannot be referred to as Pop culture product, repeating the same stamp. Furthermore, we traced how the author's concept of the archetypal notions of Angels and Demons was reflected in the novel. Thus, these results have been reached by implementing biographical approach in considering the writer's literary career; historical approach in analyzing inaccuracies in depiction of the historical events; and mythological in tracing the reflection of the novelist's archetypal concept. The benefits of this study include changing attitude to the literary heritage of the author and drawing more attention of scholars to the given novel.

Аннотащия. На сегодняшний день эклектика жанров настолько распространенное явление, что порой не представляется возможным определить жанровую принадлежность произведения. Эта ситуация, в свою очередь, отражается в размывании границ между «массовой» и «элитарной» литературой. Следовательно, существуют романы, которые не относятся к «массовой» литературе, но содержат некоторые ее элементы. Например, романы, открывающие серию книг одной тематики, или же повествующие о приключениях одного и того же персонажа. Исследуемый роман открывает серию бестселлеров о «злоключениях» профессора Роберта Лэнгдона. Наше исследование доказывает, что данный роман оригинален, так как отражает авторскую концепцию архетипов «ангелов» и «демонов»; и занимает ключевое место в творчестве писателя. Таким образом, для получения вышеуказанных результатов были применены следующие литературные подходы: биографический при исследовании тематического своеобразия творчества Брауна; исторический при выявлении неточностей в указании событий прошлых веков; и 
мифологический при исследовании авторской концепции в романе. К пользам данного исследования можно отнести изменение отношения к творчеству Брауна и привлечение внимания к дебютному роману.

Keywords: bestsellers, concept, plot, system of characters, religious evolution, hybrid novel.

Ключевые слова: бестселлер, концепция, сюжет, система образов, религиозная эволюция, роман гибрид.

\section{Introduction}

Daniel Gerhard Brown or Dan Brown is a modern American writer, who has become famous for a series of books about the adventures of Robert Langdon, a Harvard professor of religious symbology. The series include such bestsellers as Angels and Demons (2000), The Da Vinci Code (2003), The Lost Symbol (2009), Inferno (2013), and The Origin (2017). These books have been translated into 56 languages and have been sold all over the world [1].

All the novels are exploring Christian themes and historical facts and, as a result, cause controversy. Basically, all the novels can be characterized applying the same quest structure at the plot level. Therefore, the weak points and inaccuracies are alike in each book. Due to these inaccuracies the works of the author are sometimes referred to as popular fiction products or "potboilers". Thus, not each novel has been considered worthy of attention and criticism by the scholars. However, a novel exploring themes of Christianity, history of arts, and scientific discoveries requires impressive amount of research. Obviously, we cannot refer to such a novel as a 'potboiler'.

The novel which managed to get the attention of scholars and caused the biggest public outcry, thus, bringing fame to the writer was The Da Vinci Code. This novel, at the level of idea, questions the basis of Christian religion; at the plot level repeats its less successful sequels. This work as a mixture of a fast-paced plot and the application of scandalous idea of Christ's bloodline was so disputable that caused many heated debates around the book.

Nonetheless, the first and yet less thoroughly analyzed novel of the series - Angels and Demons. This piece of fiction not only shaped the author's writing style, but also showed the author's concept of angels and demons archetypes. Moreover, it revealed the novelist's attitude towards the place of religion and science in the modern society. Therefore, the book Angels and Demons certainly has an artistic merit and contains more ingenious elements than the sequels. This research is an attempt to fill the gap in the literature critical studies.

In order to understand Dan Brown's fiction it is necessary to have a closer look at his biography. He was born on June 22, 1964 in Exeter, the USA to Constance and Richard Brown. His mother worked as a church organist, and his father, a respected mathematician who wrote several mathematical textbooks, taught at the prestigious Philips Exeter Academy in New Hampshire. His parents got along well and respected each other's beliefs.

From one side there was a constant presence of scientific atmosphere, from the other, a deeply religious upbringing. In a 2009 interview the writer describes his own attitude to religion, his "religious evolution" by saying that at first he had an issue with comprehending which way to follow. This problem appeared due to the religious upbringing and then, when the author began studying scientific theories at school, he "gravitated away from religion" by claiming that he had found more sense in science. However, when asked in the same interview about his then-current religious views, Brown replied that he had come "full circle": the more science the author studied, 
the more he saw that physics becomes metaphysics and numbers become imaginary numbers. In the end he came to the conclusion that there is "an order and a spiritual aspect to science."

Another cornerstone of the author's life reflected in his works is his educational background which gave hints to the layout of secret societies which formulate one line of the intellectual plotline. The Phillips-Exeter School, which Dan Brown had attended, was a closed private school. Nowadays young people from 29 countries of the world study there. What is happening in the walls of the school is hidden from prying eyes, which already resembles a secret society.

Additionally, in the town of Exeter, there is no shortage of social informal organizations. "The Star in the Eastern Lodge", an association of free masons, has been in Exeter since 1875 [2]. In his researches aimed at writing The Da Vinci Code novel, Brown used features of the secret societies that were known to him.

After graduation, he attended Amherst College, with a degree in English and Spanish in 1986. The last year of his education Dan Brown spent at the University of Seville, in Spain. There he enrolled in a course of lectures on a subject which he poorly understood - the history of arts. At one of the lectures, an event occurred that changed the life of Dan Brown. During the lesson devoted to the work of Leonardo da Vinci, the teacher showed slides with reproductions and drew students' attention to strange details, encrypted messages or inaccurate interpretations. Then Dan Brown saw that in the "Last Supper" there has been no cup of wine on the table, and John sitting next to Jesus looks more like Mary Magdalene. Later he wrote: "For specialists in the field of art history, this was not some kind of revelation, but for most of us the idea of secret messages, encoded in great paintings, became a grandiose discovery." Since then, in the works of the great Italian, Dan sought and found secret signs, cyphers and messages. This search is also reflected in the novel The Da Vinci Code.

He then moved to California to pursue a career as a songwriter. Although he had little success in the music industry; in 1990 he wrote his first book, 187 Men to Avoid, a dating survival guide for women which had no success; it was published in 1995 under the pseudonym "Danielle Brown". [3] He also lived in Hollywood from 1991 to 1993, where he attempted to break into the singersongwriter market while teaching at a private school to make both ends meet. Eventually, he moved back to New Hampshire with Blythe Newlon, whom he married in 1997, and began teaching at Philips Exeter Academy as an English and creative-writing teacher. Around the time he started teaching; Brown read a novel by Sidney Sheldon - The Doomsday Conspiracy, and decided that he could produce a better story. With Newlon's research assistance, he began writing and by 1996 decided to quit teaching and devote his full time to pursuing a career as a novelist. Nowadays Dan Brown is a successful novelist and resides in New Hampshire.

\section{Problem development status}

Despite the uniqueness of the novel Angels and Demons there are few scholars who dedicated their works to the novel Angels and Demons. These researchers investigated the novel according to its genre, linguistic aspects, and the roles of protagonist and antagonist in the plot development. Thus, such scholars as Cherkas A and Balod A focus on the genre and the roles of the abovementioned characters in the novel; however, they do not analyze the whole system of characters. This insufficiency of a researched section of the work is a result of the prominent scholars' preference in the analysis of "serious" or "highbrow" literature but not the "lowbrow" one.

Speaking about the genre of the novel there is no unanimous opinion of scholars. Cherkas A in his article states that this novel is of the intellectual genre. Balod A, on the contrary claims that this type of a novel is of a marginal origin. Cherkas draws his conclusion on the novel's type 
through the analysis of plot development as the plot is full of unexpected twists and bulks of information about scientific endeavours, history of arts and theological issues.

Meanwhile, Balod comes to his decision through the analysis of the novel's form by stating that this type of novel can be entitled as a "hybrid novel" as it simultaneously contains all the forms of manifestation of modern popular culture: elements of a computer game, television scenario, and ready-made tourist route. Thus, the opinions of the scholars about the genre of the novel are various depending on the angle of the research.

Another aspect of the scholars' investigation is the linguistic peculiarities of the given novel. Here the approaches towards the analysis of the linguistic peculiarities of the work were applied mainly qualitative rather than quantitative ones. Cherkas and Balod use qualitative approaches in describing the choice of the language made by the author. Kosov G, a researcher, on the other hand, prefers a quantitative approach in his analysis. He presents his research of the language peculiarities of the novel in a form of statistics, where he counted how many times a certain part of speech had been used [4]. However, this statistic data is presented without a certain aim and, thus, it is vague statistics lacking order.

Despite the seeming consensus between Cherkas and Balod in the approach to the investigation of the linguistic side of the work, there is an immense gap in the angle of its employment. Such wise Cherkas underlines the role of the antagonist - Carlo Ventresca of the narration basing his arguments on the author's choice of the imagery and the emotive means of the language used in depicting the eyes, which reflected each change in hero's feelings and emotions. Moreover, these changes are caused by the complex plot development. Thus, the antagonist became the key personage in the book, according to Cherkas.

As for Balod, he preserves a more conservative opinion on this matter and suggests the primary importance of the protagonist - Robert Langdon of the story. This suggestion is made considering the typical structure of the myth which lays in the foundation of each popular culture production; more precisely, the three stages of the plot development which the protagonist completes to obtain a spiritual or material quality: "a call to adventure", "a road of trials", and "the goal" or "boon" [2]. Furthermore, Balod points out that the development of "popular" or "trivial" culture, especially, the progress of cinema industry drastically re-shaped the literary texts: now the focus is on the show-like episodes. Thus such narration requires the use of action verbs and emotive means of a language. This way the researchers investigated one section of the narration applying one approach but had different outcomes.

Next aspect of the novel is the system of characters, which is briefly touched in the scientific works of the scholars. This brief mention of the system of characters is due to the scholars' decision to analyze the role of one personage, rather than analyzing the roles of other primary and secondary personages in interaction with each other in the course of the plot actions development. The researchers investigate the roles and features of the antagonist and the protagonist respectively in the novel. For instance, Balod singles out the plotline of Robert Langdon who transforms from the ordinary teaching professor at Harvard University into the saviour of humanity. Moreover, the "superman" likes features of the hero: staying "safe and sound" no matter falling from the helicopter, being heavily beaten by the assassin, are also brought to the forefront in the article [5].

Another more complex personage is Carlo Ventresca, he was thoroughly studied by Cherkas. The complexity of this hero is purposely created by Dan Brown, who for the first time introduces the antagonist under the pseudonym of "Janus" and keeps the real identity of the antagonist secret till the last page and, thus, separates Carlo from the "Janus". Therefore, for the reader the personification of the evil is the "Janus" personage and Carlo Ventresca is a friendly priest who prevented a massive explosion and saved the city and lives of millions. Nevertheless, Cherkas 
claims that in order to perform a thorough study of the character, the deeds of Carlo should not be considered without taking into consideration the deeds of the "Janus" as they both show one person.

Further Cherkas suggests the idea that the antagonist represents the dual nature of a human being [6].

These researchers made an attempt to analyze the system of characters taking the key figures of the story: the protagonist and the antagonist separately from the other personages, and to study the features and the transformations of the already mentioned characters in the course of the narration.

To sum up it can be said that the novel Angels and Demons have been investigated from the point of view of its genre both the form and the content, linguistic aspects implementing both qualitative and quantitative approaches, and the system of characters considering the key personages like Robert Langdon and Carlo Ventresca. However, nobody managed to analyze the novel through the point of the author's concept. This insufficiency of a researched section of the work is the result of the prominent scholars' preference in the analysis of "serious" or "highbrow" literature but not the "lowbrow" one.

\section{Material and research methods}

Angels and Demons is the first book out of five that tells the adventures of Robert Langdon, a Harvard professor of religious symbology and iconology. The theme of this novel is quite topical the place of religion in modern society, where people cannot imagine their lives without technical achievements. Thus, the problem described in the book is demanding attention - the unprepared for changes society, facing rapidly progressing scientific discoveries. Accordingly, the main conflict is the one between the theology and "pure" science. Dan Brown explains his position on this matter: "Science and religion support the same truth..." [1; p. 70].

So the idea of the novel is original - the necessity of the dialogue between religion and science. This idea is a reflection of the author's concept of the religious notions: "Angels and demons were identical - interchangeable archetypes - all a matter of polarity. The guardian angel who conquered your enemy in battle was perceived by your enemy as a demon destroyer" [7]. This so called "polarity" is shown in the main conflict between science and religion: humans seek the truth differently: some in science, some in theology. It is like telling the same story in several languages, the core will be maintained. Thus, the concept was completely developed in the plot and the system of characters of the novel.

The plot recounts the story how the main hero reluctantly gets involved in a murder mystery of a scientist at the international scientific facility - CERN (Conseil européen pour la recherche nucléaire - The European Organization for Nuclear Research) [8], who is killed over a breakthrough discovery which can have profound implications in religious field. This murder is connected to the symbolic assassinations with the use of ambigrams which are words that can be read upside down as well as from the right side to the left and the reverse. There are six ambigrams, four of them represent the basic four elements (earth, water, air, and fire), one represents the name of the brotherhood, and the sixth, an enigmatic symbol is unraveled. The first victim, the scientist, is branded with the Illuminati symbol. Meanwhile, the work of the victim has been stolen and used as a tool for creating a massive explosion in which Vatican city is going to disappear from the face of the Earth. At the same time the city is the object of a worldwide attention as the procedure of electing a new pope is performed by the conclave of cardinals. Langdon and the step-daughter of the scientist are to find the "path of illumination" which will lead to the assassin and the exact location of the bomb. This path is the number of clues hidden all over Rome by Bernini who acknowledged himself as an illuminatus. However, main characters lack time as four "prefereti" 
cardinals are kidnapped, and each hour one of them is to be branded and murdered until the final explosion at the midnight. This tense situation requires the protagonist to apply all his scientific knowledge and wit to decipher the messages left by Bernini and save the theological centre of the Catholic Church. Thus, in the foundation of the plot development lays controversial idea of the conflict between science and religion.

\section{Inaccuracies depicted in the novel}

However, the idea was accomplished through the means of speculation of the historical facts and the already existed contradictions between science and religion. These speculations caused lots of negative reviews, though it is necessary to keep in mind that it is a fictional work, not a book on history.

The brightest example of such speculation in the book is the story, where Galileo is presented like the one who had suffered from the church dogmatism. This side of the story is partially true because the story of Galileo's Affair is more complex than the one which is presented in the novel. Larissa Johnson, a scholar, claims that:" The problem was that Galileo had no real proof of his ideas, as much of his telescopic evidence applied equally to the Ptolemaic and Copernican systems. Further, he could not explain how his system worked, or how the earth could move at all." [9]

Moreover, she explains that Galileo was permitted to study the Copernican system and told to treat his idea as a hypothesis due to the absence of conclusive demonstration. Therefore, this storyline in the book is presented in a different angle. Even more astonishing and falsie speculation is noted by James J. Drummey about Copernicus: "Outspoken scientists like Copernicus ...were murdered. Murdered by the church for revealing scientific truths..." [1; p. 31]. This statement is not true because Copernicus died at the age of 70 from a natural cause: “...was seized with apoplexy and paralysis" [10].

Thus, it is clear that the church had nothing to do with the death of this outstanding scientist, and J. Drummey is right noting this falsification of the real cause of death.

Another contradiction depicted in the novel is the statement of the protagonist - professor Langdon that science and religion are "oil and water". He explains:" Since the beginning of history," he says, "a deep rift has existed between science and religion" [1; p. 27]. This claim might be adopted in modern society if the history, especially Western, is not taken into consideration. This point is nicely presented by Adrian Wyard who wrote:"... Western science emerged from within a religious (Christian) cultural context. Galileo was a devout Catholic, and Isaac Newton was certainly a fervent believer. Both had their problems with the church authority and orthodoxy, but they were undoubtedly religious." Accordingly, the term "oil and water" is far from objective reality.

Furthermore, this so-called "deep rift" cannot exist in modern society as Vatican had already shown its support to the field of scientific achievements before the book was written and published. In 1987 Pope John Paul II made a truly "revolutionary" statement claiming that: "Science can purify religion from error and superstition; religion can purify science from idolatry and false absolutes. Each can draw the other into a wider world, a world in which both can flourish..." [11]. The scholar Robert John Russell sums up the idea of the Pope about the necessity of such a constructive dialogue between science and religion pointing out that: "the isolation between the Church and the scientific community is not a real option" [12]. Thus, it is obvious that the push for mutual collaboration between science and religion was done 13 years earlier than the publication of the novel in 2000 . 
Dan Brown does not react on the "biting" criticism, instead, he chose to do his work and hope that others "will share your taste". Furthermore, the author states that he writes the books that he "would want to read". Obviously, tastes differ and universal acceptance is impossible.

Considering these facts the novel Angels and Demons represents the author's attempt to adopt pervasive idea of science and religion juxtaposition as the main conflict. However, those reviewers did not take into consideration that the aim of the author was to make readers contemplate over alternative versions of historical events.

\section{Results and discussion}

The success of the juxtaposition between science and religion is reached through the application of the system of characters in which the heroes are divided into two camps opposing each other. Each camp represents dramatically exaggerated idea of the absolute impossibility of a dialogue between the scientific community and the religious establishment.

In this system the majority of characters are static and one dimensional only serving one function of the plot development apart from the antihero - he is thoroughly created and sophisticated. Such a system is typical for all the novels written by Dan Brown where the protagonist is a cliché character, a collective picture of an average professor. The implementation of cliché characters is a typical feature of pulp fiction. However, we investigate the first novel of the series, therefore, referring to the book as a pulp fiction product is not fair.

The protagonist is Robert Langdon - a Harvard Professor of Art History and Symbology (religious). The author chose this surname to his protagonist because of John Langdon, a professor of typography at Drexel University who is known for his creation of ambigrams, typographical designs that can be read in multiple ways; for example, both right side up and upside down. An example of Langdon's ambigrams appeared on the cover of the first edition of Brown's novel Angels \& Demons, and other ambigrams featured throughout that novel were also designed by Langdon. On the acknowledgments page, Brown calls Langdon "one of the most ingenious and gifted artists alive ... who rose brilliantly to my impossible challenge and created the ambigrams for this novel"' 1 ; p. 22]. John Langdon also created the logo for the fictional Depository Bank of Zurich, which appears in The Da Vinci Code film. As a literary personage Langdon is portrayed by his female colleagues as having "an "erudite" appeal-wisps of gray in his thick brown hair, probing blue eyes, an arrestingly deep voice, and the strong, carefree smile of a collegiate athlete" [1; p. 8].

According to the novel the hero was forty-five years old "a bit of an enigma - a man caught between centuries" because he could easily communicate with youth and at the same time he was a strict disciplinarian who often gave lectures at museum openings. Moreover, it can be said that he could keep attention of public and he is rather an open-minded personality. As it has already been mentioned above the author grew up at the campus of the Exeter Academy so the protagonist is a collective image of the professors at the Academy. A more idealized version of a teacher with an athletic appeal of a swimmer, a gentleman manner of behavior, and superman abilities. The author presents a minor detail of the hero - "Mickey Mouse" watch, which gives hint to readers about the character of the protagonist. It can be said that a man wearing "a pair of chinos, a turtleneck, and a Harris tweed suit jacket" and the watch is an erudite who despite being adult is a childlike naïve [1; p. 6]. Being a gentleman Langdon at the crime scene cares about the feelings of the lady, whose stepfather was brutally murdered: "He takes his handkerchief and lays it on the floor over Leonardo Vetra's eyeball".

Further the author explains the decision of the hero to stay and help solve the murder by the following statements: "There was also a question of conscience. With Kohler ailing and Vittoria on her own, Langdon knew that if his knowledge of the Illuminati could assist in any way, he had a 
moral obligation to be here. There was more, though. Although Langdon was ashamed to admit it, his initial horror on hearing about the antimatter's location was not only the danger to human life in Vatican City, but for something else as well. Art." These statements characterize the personage as eager to help, following a moral code, honest, and a true connoisseur of art. Within the events of the story the protagonist proves his eagerness: "I may be able to figure out where they're going to be killed." Indeed he is the one to figure it out.

The erudite trait is presented throughout the story, the places of the assassinations and the secret "Church of Illumination" have been found by the protagonist who applied all his scientific knowledge to unfold the secret passageways in the city and to solve the charades left by Galileo. More precisely, according to the novel "John Milton was an Illuminatus. He composed the poem for Galileo to publish in Folio 5... far from the eyes of the Vatican." [1; p. 114]. The poem contained a secret path to the "Church of Illumination" and on the way there were 4 sacred places devoted to the ancient elements of science: Earth, Air, Water, and Fire. These milestones of the path were commemorated by Bernini in architecture so the places are to be used for ritual assassination of the cardinals to avenge the victims of the inquisition.

The protagonist while solving the charades also gives explanations of certain phenomena sometimes like a historical encyclopedia. This information is mainly presented in the form of a dialogue with other characters: "The symbol is Masonic?" "Actually, no. It's Illuminati. They called it their 'shining delta.' A call for enlightened change. The eye signifies the Illuminati's ability to infiltrate and watch all things. The shining triangle represents enlightenment." In addition this character reacts logically each time even though he is deeply impressed: "Despite the madness around him, his first reaction was logical. Academic rejection" Such a reaction seems to be unreal in the moment of emotional tension.

Moreover, through the protagonist the author's passion for conspiracy theories is revealed, on the dollar bill: "The writing under the pyramid says Novus... Ordo..." "Novus Ordo Seclorum," Langdon said. "It means New Secular Order." "Secular as in nonreligious?" "Nonreligious. The phrase not only clearly states the Illuminati objective, but it also blatantly contradicts the phrase beside it. In God We Trust" [1; p. 60].

The same sign of the "Delta" can be traced on the US Presidential Seal, so the hero is not only a truth-seeker like "Indiana Johns" but also a faithful follower of the conspiracy theories always ready to unfold the truth hidden in the ancient mysteries. To sum up, the protagonist is a typical popular literature personage who is simply structured no "enigma" hidden - an archetype of a truth-seeker. The appearance fully coincides with actions and thoughts of the character.

The antagonist, on the contrary, is the result of the author's hard work and talent of good story telling. Thus, in the novel under our investigation the main villain is represented by Chamberlain Carlo Ventresca who appeared as a secondary hero — a friendly priest. The fact that Carlo Ventresca is a negative personage becomes known at the denouement. Dan Brown purposely brings Carlo Ventresca to the forefront of the composition under the pseudonym Janus to create an illusion of a separately existing main negative character as Janus was the head of the anti-science camp of a radical religion. It can be said that the clergyman personifies the story of "Janus" from the ancient Roman mythology. However, "Janus" from the mythology had a distinct duality - two faces. In this book, on the contrary, this duality is so veiled that the tension is kept till the last page.

Therefore, the main negative character is represented in the novel from two sides - visible (Janus) and hidden (Carlo Ventresca). This way all the evil acts committed by the main negative hero of the novel are perceived, above all, as the actions of Janus. They occupy a central place in the events of the book. The author perceives Janus as an unattainable master of the fate of innocent people: "He still could not understand the degree of influence of the person hiding under the name 
Janus, and the power of the ancient brotherhood, which he headed" [1; p. 81]. The hero himself created a halo of secrecy with the help of the Illuminati legend. Janus independently developed a plan to prove that religion rises above science, and science, in turn, is the main evil. But to do most of the "dirty work," that is, perverted murders, he entrusts to Assassin. It can be assumed that Janus gives the execution of the plan to another person because of the fear of being noticed by the police, the inability to commit crimes, and transference of sin to an unbeliever.

This suggests that Carlo Ventresca was a good strategist who not only skillfully watched everything from the outside, but also, as it seemed to him, reduced the payoff for his sins to a minimum. After all, he prayed for every killed person, but at the same time justified himself by the fact that the murders were committed in the name of God. In this inner state of mind, the opposition of good and evil, angels and demons is observed.

Purposely abandoning the descriptions of Janus' appearance, Dan Brown gives a detailed portrait characterization of chamberlain Carlo Ventresca. This is a young priest who was an assistant of the late Pope. The clergyman was about forty years old; by the standards of the Vatican, this is a youthful age, which presumes the position of a chamberlain. Therefore, there is nothing surprising in the youth of the protagonist. However, Carlo's clothes differed from the pompous heavy cassocks of Catholic monks, he had a simple white one which "emphasized the athleticism of his figure" [1; p. 175].

A distinctive feature of Carlo Ventresca's image is that he does not carry the attributes of priests with him - he does not have a cross and prayer beads. The hero has brown hair and green eyes. The author assigns a special role to the eyes of his hero. Throughout the work, they reflect all the changes in feelings and mood of the character. At the first acquaintance with a chamberlain, his eyes are "radiate with an inner light". For the main positive character, Robert Langdon, the eyes of the antagonist make the impression that "in their bottomless depths there is a fire of some mysterious knowledge". This is another subtle hint of the writer, who says that Carlo has information inaccessible for others. Simultaneously with the fire in the eyes of the chamberlain, fatigue and suffering are read. Even here the author creates a contradiction, thereby emphasizing the essence of his character.

Each event of the plot brings a new colour to Carlo's eyes. When the chamberlain spoke about the disaster that killed his mother, loneliness was read in his eyes. In the period of the tragic events in the Vatican, the Swiss Guards noted the harshness and severity that appeared in the eyes of the priest. After the incident in the library, during which Robert Langdon could have died, the author notes that the priest's eyes "lit up with some kind of new fire" [1; p. 407]. Dan Brown does not explain the reason for this transformation; we can assume that this is another indication to the reader of the evildoer. At the moment when the inspiration comes from above, his gaze is full of determination - "the gaze of a person who controlled his actions" [1; p. 575]. This phrase contains the essence of the negative hero: despite all the obstacles, internal struggle, perhaps the call of conscience that resisted going against the laws of morality, church and state, till the end, Carlo keeps the situation under his tight control.

Giving such a detailed description of his hero's eyes, Dan Brown sought to convey the feelings and thoughts that occur in mind of the disguised villain. Cruelty is equal to the infinite love of religion, fatigue marks a goal achieved, savagery is an obsession and religious fanaticism, and pity in his eyes characterizes the clergyman as a selfish person. After all, to look with pity is like looking from high - Carlo Ventresca equates himself to God on earth. The face is less expressively described. Such epithets are given to him by the author at various situations: "full of horror," "suffering," "full of fatigue." At the moment when he was told of Cardinal Lamassé's death, "the chamberlain looked up, and by the expression of his face it was clear how he was suffering". 
This gives the reader a reason to assume that the chamberlain does not treat his victims indifferently; he is really embarrassed by their death. Only during the illumination from above "joy spread over his face". It was at this point that the writer compares Carlo Ventresca with Jesus Christ: "Suffering from wounds, half-naked, the priest was something like Christ". And the chamberlain himself by his actions sought to achieve the impossible, to equate his actions to the actions of God.

The basis for Janus' actions was the ancient ritual of La purga in 1668. "The church branded four Illuminati scientists with the symbol of the cross." The purpose was - to purge their "sins". After the brandings, the scientists were "murdered, and their bodies were dropped in public locations around Rome as a warning to other scientists not to join the Illuminati."' $1 ;$ p. 144].

Therefore he seeks to recreate La purga, but the executors this time are not the clergymen, but the representatives of the order involved in science. The reader perceives the killing of four cardinals as the work of the Illuminati Janus, because it was he, who gave orders to Assassin. He alternately stigmatizes the clergyman, kills cardinals and leaves them at various religious sites. Moreover, in causing mortal harm to people, Assassin uses four elements: earth, air, fire, water. This is a kind of opposition of the symbol of the church (the cross) to the symbols of science.

At the same time, Carlo Ventresca's actions show his positive nature. After the death of the Pope, he became the head of the Vatican, but his power did not border on pride. The author makes his image controversial. On the one hand, Carlo controls his plan and the current situation in the Vatican, but on the other hand, even in times of hardship, he is polite, gentle, and calm. Meeting Robert Langdon and Vittoria Vetra, the clergyman himself "pushed three chairs to his table". This characterizes him as a person who does not use his position. His power is manifested in the actions - instructions of the Swiss Guard. He completely controls the situation, gives logical orders, and from these instructions characteristics of a priest are observed: "Let God alone govern you in your choice". Carlo Ventresca's desire to raise religion over science is so strong that even the need to inflict pain on himself does not stop him. In order to expose the head of the CERN as Janus, the chamberlain stigmatizes himself, thereby positioning the innocent Maximilian Kohler as Janus. Also, the act of the priest says that he suffers along with other stigmatized victims - scientist Leonardo Vetra and the four cardinals.

At the climax of the plot, the acts of Janus and Carlo Ventresca reach their peak. Chamberlain plays a whole mystical performance, imitating the appeal to him of God: "The last act of the drama has begun. "With God," he thought (chamberlain), "with God!" [1; p. 569]. A cleric finds antimatter and pathetically disposes it, dropping it into the river from a helicopter. Carlo's return to the ground is becoming hyperbolic. He appeared in front of a multimillion crowd as an angel on the roof, who not only saved the population of the Vatican and nearby countries from the devastating explosion, but also united people by religion, faith in God: The main goal of the chamberlain has been achieved. He proved that faith can work wonders, save not only bodies, but also souls. But all these were accomplished at the price of deception, hypocrisy, and murder. True, the hero does not think so, because the character sincerely interprets all his actions as indications of God.

Nevertheless, Carlo Ventresca's actions consist of two components - love of God and hatred of science. Carlo became a devout Catholic thanks to his mother. She was a deeply religious person and since the hero's childhood she told him that the Creator is his father: "Now only God is your father, you are a child of the church". Of course, such statements flattered the future of the priest. Carlo's hatred of science was awakened by an accident, when the church was bombarded, and as a result his mother died. A ten-year-old boy survived, it was marked by a miracle of God. The clergyman, who later became the Pope, took on the upbringing of young Carlo. These events marked the beginning of Carlo's actions, which he carried out many years later in the future. Furthermore, Dan Brown gave Carlo Ventresca an incredible desire to achieve the goal, so the 
chamberlain gives a full account of his actions. Apparently, this also prompts him to tell the truth to the cardinals who have gathered in the Sistine Chapel, as well as to the main positive characters, Robert Langdon and Vittoria Vetra. The decisive impetus for the commission of all the crimes was the fact that the Pope supported the scientific discovery of Leonardo Vetra, as well as the recognition of the head of the Catholic Church that he had a child. For Carlo Ventresca such revelations were unacceptable and he decided to prove to the whole world the superiority of religion over science.

Carlo Ventresca remains true to his convictions till the end. This characterizes him as a strong, determined man. He is striving to prove everyone the nobility of his actions: "The wounds on my body cry that evil is alive. But at the same time they proclaim that the work of God will triumph! "[1; p. 606] Only the truth, heard from the oldest Cardinal Mortati, that the Pope's child is Carlo Ventresca, brought him back to the real world, more precisely, with the help of science and modern medicine Carlo was brought into the world, so the late Pope did not break the vow to God.

The new information has made a strong impression on Carlo, he realizes that he has committed the incorrigible and, before the eyes of people gathered at St. Peter's Square, produces an act of self-immolation. This last act symbolizes love for God and at the same time the deepest despair, because it is impossible to live with everything he has done. Dan Brown's skill of writing fiction is embodied in the personage of Carlo Vetresca. This character is a vivid example of combining opposites in one person. The hero, created by Dan Brown, embodies the human contradictions. These are internal experiences about the divergence of the laws of science and religious canons. This is a struggle for justice, which pushes a person to crimes, while violating God's commandments.

Nonetheless, all the characters of the work are related to each other, they depend upon each other as each character fulfills a particular function. A function of an executioner is given to the assassin. This character is described as a personification of pure evil: "...looked into the inky void of his captor's eyes and swore he saw hell itself." Furthermore, the antagonist is enjoying his job and feeling honored for accomplishing the task: "He was a warrior like his ancestors... Now he had been given the honor of spilling first blood....his body - a well-tuned, lethal machine..." The author compares the personage with "lethal machine" thus underlining the lack of such human emotions as mercy, compassion, and humanity. However, being a "machine" having instincts of pleasing his body and killing innocent people, the hero dies a "silly" death: a lethal fall out of the window. Nonetheless, with his death a justice is preserved: Langdon helped Vittoria Vetra to escape from the captor and avenge her father. No pity, no regrets upon the death of the hero as it was mentioned above he was just a "tool" in the hands of the "Janus".

Another personage who is used to show the complex nature of the "Janus" is his mother Maria. This personage appears only in Carlo's memories of the past and he idealizes this image. Accordingly, she is an archetypal image of a "Good Mother" as she is always described in a positive manner: "He could still see his mother, kneeling at the pew, blowing him a kiss...The blessed Maria!", "Every night Carlo prayed for his mother." [1; p. 171] Additionally, she symbolizes "Virgin Mary" because being a nun she got fertilized artificially with the help of medical intervention. For Mary this child meant a wonder, and being a nun she perceived it as a miracle in a religious sense. Therefore, she sacrificed her life to save her son by helping him to hide in the church so that bombardment would not reach him. This act shows that she loves her child and she entrusts her son to the church. Thus left to the responsibility of the religious establishment Carlo grew up an adult detesting science, as he blamed scientific progress in invention of a bomb and in the death of his mother. 
There are a few episodic characters whose significance lies within the frames of the role of the sacrificial scapegoat. These heroes are the four cardinals who were ritually branded and killed. Each of them was assassinated differently: Cardinal Lamasse had his lungs punctured; Cardinal Guidera was burned alive; Cardinal Ebner was suffocated by the dirt; Cardinal Baggia was drawn. This choice of the cause of the death is symbolic because the four elements (earth, air, fire, and water) are of the pagan origin. It is common knowledge that pagans were hunted and were forced into baptism. The author uses these characters to reveal the nature of the assassin and to create the suspense in the work.

If the camerlengo and the assassin represent the camp of "anti-science", the "anti- religion" camp is headed by Maximillian Cohler - the director of CERN. The head of this facility is depicted as an atheist who respects only "pure" science - physics. However, like Carlo Ventresca, this personage suffered from the childhood trauma that shaped further life and preferences: his religious parents refused from medical treatment of their son which resulted in paralysis. Therefore, few judged him for his views: "... the horrific story of how he crippled was lore at CERN, and there were few who blamed him for his bitterness...not for his sworn dedication to pure science" [1; $p$. 26].

Although his claim that: "Religion has always persecuted science" is the result of that event in his childhood, he had many followers in CERN who shared his opinion. Even though this character is minor and his statement is exaggerated, he serves the purpose of creating opposition between the world of science, nuclear research and the world of religious dogmatism. This binary opposition can be noticed even in the appearance of the heroes not to mention the actions. The head of the research facility is presented as a rather unfriendly "cold" person. There is no detailed description of this personage - the author mentions the "computerized" voice and "dead gray" eyes of the hero. Such an unattractive appearance created an atmosphere of fear and respect at CERN.

Moreover, unlike Carlo who was an ordinary priest, Cohler had a position and was compared to "König - King". The kingdom of Cohler - CERN is metaphorically entitled as a "Glass Cathedral" If "glass" refers to the material from which it was built, the word "Cathedral", which generally denotes an architectural monument for religious services, is a metaphor for a heart, a sacred place for scientists. Speaking about the throne of Cohler, it was extraordinary - his wheelchair, which resembled a "mobile command center" with the number of equipment as there were: "multiline phone, a paging system, computer screen, even a small, detachable video camera" $[1 ;$ p. 12]. Such heavy ammunition describes the person as controlling the situation, having real power. Moreover, the manner of Cohler's speech each time he corrected Langdon, was like the protagonist knew less about science and felt humble compared to Cohler. This way he purposely kept distance from people. Nevertheless, the "King" helped to solve the charade with the real evildoer by giving Langdon a memory card from his camera where Carlo's conviction had been recorded. Accordingly, the inner side of the hero does not coincide with the outer side. In other words, it can be said that the appearance was like a shell, hiding a kind heart and a nature of a truthseeker. The main motive behind his actions was the preference of "pure" science over church dogma.

Moreover, the author uses not only personages to create a binary opposition, but also the centres of the scientific researches and the Catholic religion. Thus, CERN is opposed to Vatican; particle physics to Holy Scriptures. This opposition is also noticeable in the notorious stories of the contrasting parties: Carlo and Maximillian.

However, not everything is that smooth with the division of the characters into the confronting groups in the novel. The Pope and Leonardo Vetra are the two minor characters that support the idea of the dialogue between the science and religion; though, they have been already 
murdered by the moment of narration. These two heroes are significant for the development of the main conflict as they symbolize the faith in divinity and the integration of science and religion. This integration is represented through Leonardo Vetra's profession; he is both a priest and a scientist. Furthermore, his research could have brought the end to doubts: "He claimed God's handwriting was visible in the natural order all around us. Through science he hoped to prove God's existence to the doubting masses. He considered himself a theo-physicist." This scientist is branded and killed. The Pope is also loyal to the science and approves Leonardo's research. The head of the church is shown as: "Supreme father, counselor, friend"[1; p. 309]. Unlike the branded scientist, he is poisoned. Thus, the personages working on establishing close links between the opposed sides are purposely removed from the storyline to create a conflict.

Another crucial for the storyline character is Vittoria Vetra. She is also a member of CERN though she does not support the idea of "anti-religious science". Her role in the story is a friend, as she is helping Langdon in finding "the path of illumination". The author portrays this personage as "lithe and graceful...tall with chestnut skin and long black hair..." - another idealized version of a scientist, who is "a strict vegetarian and CERN's resident guru of Hatha yoga" and simultaneously, a "Bio Entanglement Physicist" This extraordinary combination was created purposely to show the possibility of a harmony between two contrasting sides: particle physics and yoga. Moreover, "entanglement" serves here to reveal the interconnection between the eco systems, so this personage reveals the author's point of view that science and religion are two languages explaining the same phenomenon. By adding this personage into the system of characters Dan Brown shows the protagonist's positive features. Furthermore, in the dialogues between this hero and the protagonist the history of the ancient brotherhood and essential scientific notions are explained to readers.

In general it can be said that some events described in the book took place in the history but they are exaggerated and sometimes shown from the different angle. Although, this reversed picture of history is conventionalized by the creation of the new conflict between science and religion, it reflects the author's concept of the archetypal images of angels and demons.

\section{Conclusions}

In conclusion it can be said that Dan Brown is a representative of modern literature which reflects the needs of the majority. Thus, this type of literature contains "hybrid novels" as they incorporate all the forms of popular culture from a computer game to excursion routes. Even though these novels are structurally forms of pop culture, some of them have certain artistic merit. The book Angels and Demons is one of them.

Despite the eclectic nature of its form it represents the curious concept of archetypes which lays in the foundation of the content. The two dialectic categories of form and content were successfully implemented by the author in the novel. Dan Brown managed to explain his concept through the main idea of the novel - science and religion are alike; as they serve one purpose of exploring a fundamental truth, lying in the core of a human existence - energy is a source of creation. However, the way humans search the truth varies dramatically; thus, appeared the main conflict between science and religion. This division into contrasting parties was reflected in the system of characters.

Moreover, this novel gave a push to the further development of the Robert Langdon series of books. The sequels caught more public attention than the current novel. Since the protagonist and plot structure were almost the same in each book scholars were reluctant to dedicate their time and effort to the profound analysis of this piece of fiction.

Nonetheless, this novel is worth of attention and a more thorough investigation of the genre is required. This genre cannot be classified and labeled as the "marginal" belonging to the pulp fiction. 
Furthermore, it would be curious to study the whole series of Robert Langdon's adventures through the point of the author's style development. As the pattern of writing might be changing, and it is not yet certain to which side of the literary hierarchy it is floating.

Sources:

(1). Dan Brown. https://danbrown.com/\#author-section

(2). Den Braun. https://clck.ru/MU7Cq

(3). Dan Brown. https://www.britannica.com/biography/Dan-Brown

(4). Coolib.com. www.coollib.com/b/112725/la

(5). Balod, A (2005). Den Braun I roman budushchego, In setevaia slovesnost'. 2(5), https://www.netslova.ru/balod/db.html

(6). Braund D. (2014). Rome and the Friendly King (Routledge Revivals): The Character of Client Kingship. Routledge.

(7). Dan Brown novels. https://www.danbrown.com/novels/davinci_code/faqs.html.

(8). CERN. https://home.cern/about/who-we-are/our-history.

(9). The Myth of Conflict in Angels and Demons. https://clck.ru/MU9GV

(10). Nicolaus Copernicus. https://en.wikipedia.org/wiki/Nicolaus_Copernicus.

(11). John Paul II www.inters.org/reflection-on-John-Paul-II-science-religion.

(12). Interdisciplinary Encyclopedia of Religion and Science. https://clck.ru/MU9k7

Refrences:

1. Campbell, J. (1968). The Hero with a Thousand Faces , Princeton, MA.

2. Brown, D. (2006) Angels and Demons. USA, NY, Pocket Books publisher, premium edition, 736 .

\section{Список литературы:}

1. Campbell J. The Hero with a Thousand Faces, Princeton, MA. - 1968.

2. Brown D. Angels and Demons. USA, NY, Pocket Books publisher, premium edition, 2006. $736 \mathrm{p}$.

Работа поступила

Принята к публикацฺии

в редакиию 03.02.2020 г. 09.02 .2020 2.

Ссылка для циитирования:

Muratova E., Pulatova D. Angels and Demons Novel - a Milestone in Dan Brown's Creative Work // Бюллетень науки и практики. 2020. Т. 6. №3. С. 571-584. https://doi.org/10.33619/2414$2948 / 52 / 69$

Cite as (APA):

Muratova, E., \& Pulatova, D. (2020). Angels and Demons Novel - a Milestone in Dan Brown's Creative Work. Bulletin of Science and Practice, 6(3), 571-584. https://doi.org/10.33619/2414-2948/52/69 